How to cite: Vigh, M. (2019) The Mineral Springs of Malnaş Băi. 2019 "Air and Water - Components of the Environment" Conference Proceedings, Cluj-Napoca, Romania, p. 419-426, DOI: 10.24193/AWC2019 41.

\title{
THE MINERAL SPRINGS OF MALNAŞ BĂI
}

\author{
Melinda VIGH ${ }^{1}$ 冈
}

\section{DOI: $10.24193 / \mathrm{AWC2019} 41$}

\begin{abstract}
Malnaş Băi is situated in the south of the postvulcanic alignment of the volcanic mountains of the Oriental Carpathians. Underground waters in their way to the surface are strongly charged with mineral salts and gases. So mineral springs appear along the structural faults. It falls into the category of alkaline waters. In Malnaş Băi, the most important spring is Maria, where the water is capitalized by bottling. The other springs lie on another alignment, right in the center of the resort. Quantitative-quality determinations of water have been made since the beginning of the 20th century. At the other springs a measurement campaign was carried out in December 2018. Different parameters were determined on the field and in the laboratory.
\end{abstract}

Keywords. mineral water, geological structure, hydro-mineral reservoir, spring, parameters, standard deviation, fixed residue.

\section{INTRODUCTION}

\subsection{Physical-geographical conditions}

Malnaş Băi is a village in Malnaş commune, Covasna County. It is situated on the right bank of the Olt River, in a depression area, in the eastern extremity of the Baraolt Mountains, at an average altitude of $570 \mathrm{~m}$. The baths are located on the road between Sfântu Gheorghe, 23.4 km south and Miercurea Ciuc, 48.6 km north. The relief in the depression corridor has mild slopes, with heights of 500-800 $\mathrm{m}$. These level differences are due to the succession of the three Olt terraces.

The geological structure of the area is the result of a strong tectonic activity with several major fracture lines. Faults facilitate the lifting of postvulcanic emanations to the surface, which trains the water reserves encountered in the path.

The hydromineral deposit comprises two superimposed aquifers. The lower one is of the Cretaceous age of the fault and fractural type, with marno-limestone deposits (Szekely, 1980). These waters have a strong mineralization. From here comes the most important spring, Maria, as well as the drills 1, 2, 4, 10, 11, 801, 802 used for bottling. The upper aquifer is permeable, of Pliocene and quaternary age, in the deposits of the Olt meadow, with a weaker mineralization. Most springs originate from this aquifer: Ileana, Mioara, Victoria, Padi, Principal, Szemviz, etc., as well as drills 8 and 9. (Munteanu, 2011).

\footnotetext{
${ }^{1}$ Babes-Bolyai University, Faculty of Environmental Science and Engineering, Cluj, Romania E-mail: vmelindap@yahoo.com
} 
Harko points out that some of the mineral springs originate from terrace II at 560 $\mathrm{m}$, where andesite blocks predominate, and the other part originates from terrace III at $810 \mathrm{~m}$ where the substrate is sand-andesitic (Harko, 1972).

$\mathrm{CO} 2$ emissions are of juvenile origin, which dissolve in ascending water, or come to the surface in the form of mofetta. The carbon dioxide in the presence of water turns into carbonic acid, used in the production of soda, in sparkling wines and in brewing. In the past it was bottled in $20 \mathrm{~kg}$ cans, 65 to 70 cans/day. It was considered to be the purest acid in the country, without odor or taste, which was used to enrich other mineral waters in Covasna County.

From bioclimatic research it is clear that temperature, air humidity, wind and atmospheric pressure are the main factors in the location of a special, sparing, sedative-indifferent microclimate. In the resort the temperature is moderate $\left(8^{\circ} \mathrm{C}\right)$, with mild winters and cool summers, precipitation is moderate $(700 \mathrm{~mm})$ and air mass dynamics is poor $(1-2 \mathrm{~m} / \mathrm{s})$, which gives the place a shelter nature. Under conditions of solar radiation the comfort potential is 60 - 90 days/year.

The water flow, chemical composition of the springs, and carbon dioxide concentration depend primarily on the amount of precipitation and the crossed bed layers. The water flow of the springs in the Malnaş Băi ranges between $0.21-0.27$ 1/sec. (Harko, 1972). The concentration of mineral salts in spring waters is influenced by the layers of rocks that these waters cross in their ascension to the land surface as well as the speed of ascension. At the same time, ascension waters are loaded with different gases, primarily carbon dioxide.

In these conditions the springs have a varied mineralogical composition, which can be used for internal and external cures. The springs have alkaline and salty mineral waters with varying content of carbon dioxide. Due to the curative properties water from the Maria Spring has been redeemed since ancient times, in the form of baths and internal cures.

\subsection{Springs}

Maria Spring is situated at an altitude of $545 \mathrm{~m}$, and the water is of the artesian type going up from a depth of $156 \mathrm{~m}$. This spring is the most famous due to its very complex mineral composition and beneficial effects on the human body. From a medical point of view, the water of the spring is classified as alkaline (Na, HCO3) in the slightly salty carbonate subtype $(\mathrm{CO} 2, \mathrm{Na}, \mathrm{Cl})$ and with relatively low $\mathrm{I}, \mathrm{Ar}$, $\mathrm{Li}, \mathrm{Br}, \mathrm{H} 3 \mathrm{BO} 3$ and Fe content (Munteanu, 2009).

In the literature, according to author or physician, the water of the Maria Spring is defined differently as alkaline, bicarbonate, chlorine, sodium, carbonate and hypotone, with certain particularities: calcium, magnesium, iodine, ferrous. Due to the high concentration of $\mathrm{NaHCO} 3$ and $\mathrm{NaCl}$ it is classified as medicinal water.

The 1909 label defines it as "sour, alkaline, natural water, medicinal water spring". The 1926 label mentions "natural alkaline mineral water." On a water bottle for export to Germany is mentioned: "Heilquelle Maria Malnaş natürliche", specifying: "jodhaltiger natrium-hydrogencarbonat-chlorid-sauer". Starting in 2013, it is marketed in ceramic bottles "Malnaş Aqua Telluris", therapeutic water. It is actually the water of the Maria Spring. 
The Siculia probe (801) was drilled in 1897 on the Olt terrace, at an altitude of $635 \mathrm{~m}$, as additional bottling capacity to the Maria Spring. The depth of the shaft reaches $156 \mathrm{~m}$ with a flow of $2500 \mathrm{l} / \mathrm{h}$, and the relative carbon dioxide concentration reaches 97\%. In 1899 it was characterized as an alkaline, salty, sour water. In 1904, Dr. Nuricsány József made his analysis: "It is one of the best alkaline salty waters, because the amount of alkali, sodium bicarbonate and salt exceeds internal sources, and even better than foreign sources previously known from a medical point of view "with a water temperature of $12^{\circ} \mathrm{C}$. At the beginning of the century, "Pastilele Siculia" ("Siculia Pills") were patented, where 15 tablets contain as much active salt as one liter of Siculia water (Kisgyörgy, 2009).

\section{Springs from the lower Olt River terrace}

They string out along the main road, being designed for public consumption.

Ileana Spring is a bicarbonated, chlorinated sodium water (Jánosi, 2005). It has sour and salty water. At the 2010 measurements by faculty students, the water temperature was $11^{\circ} \mathrm{C}$, the flow rate was $0.022 \mathrm{l} / \mathrm{s}$ and $\mathrm{pH}$ was 8 . The Mioara Spring has salty and salty water, with a higher concentration than the water in the Ileana Spring. In 2004, a flow rate of $0.010 \mathrm{l} / \mathrm{s}$ was measured, and in 2010 the flow rate was $0.012 \mathrm{l} / \mathrm{s}$, temperature $-10^{\circ} \mathrm{C}, \mathrm{pH}-8$. The Victoria Spring is a bicarbonate sodium water with high calcium and chlorine content. The flow is very low, in 2004 it was found dry, and in 2010 it was just dripping. The Main Spring is a bicarbonate, chlorinated sodium water. In 2009, the $\mathrm{CO}_{2}$ concentration was $1452 \mathrm{~g} / \mathrm{l}$ and the mineralization was $5512 \mathrm{mg} / \mathrm{l}$. In 2010, the flow was $0.110 \mathrm{l} / \mathrm{s}$ and the temperature was $11^{\circ} \mathrm{C}$. A label from 1902 was found, the water being referred as dietary mineral water. Szemviz Spring has water rich in sodium, calcium and hydrogen carbonate (Jánosi, 2005). It contains $2.48 \mathrm{mg} / \mathrm{l}$ sulfate, $1188 \mathrm{mg} / \mathrm{l}$ carbon dioxide. In 2010 the temperature was $17^{\circ} \mathrm{C}$ and $\mathrm{pH}-8$.

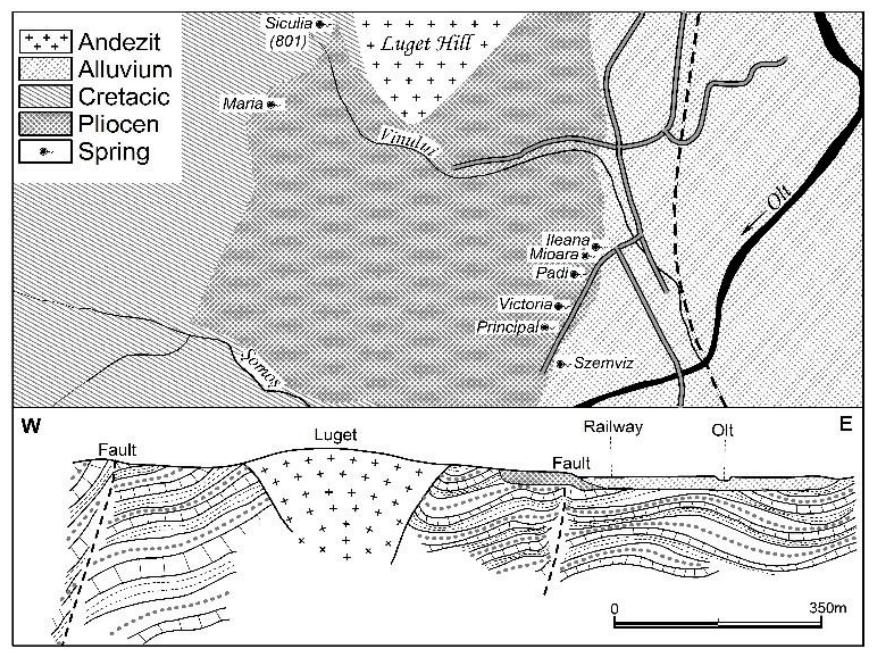

Fig. 1. The geology of the mineral springs area (adapted after Szabó et al.) 


\section{DATA AND METHODS}

The database comes from the literature and from field measurements. Old data have been gathered from books, articles and labels of springs and bottled waters (Maria Spring, Siculia probe). They refer to the concentration of the major anions and cations. Labels are from the years: 1902, 1906, 1926, 1943, etc. Recent measurements were executed in 2004 and 2010. They focused primarily on flow, temperature and $\mathrm{pH}$.

In November 2018, a campaign of measurement was carried out, when the sampling was done in a sunny but cool weather, preceded by rain and snow. The samples of water harvested come from 6 springs: Mioara, Ileana, Victoria, Principal, Szemviz and Padi. The Maria Spring could not be measured because water is captured and used strictly for bottling. Instead, from the concentrations of the ions from the literature, the mean value for the representative ions as well as the standard deviation was calculated, resulting in the final percentage error. The temperature and flow were measured on the spot. In the laboratory, the following parameters were determined with the Consort C933 and WTW 720 multiparameter in the samples: $\mathrm{pH}$, redox potential, ion content, salinity, TDS. Fixed residue was also determined using the instrument Memmert 100-800 oven, glass desiccator and Ohaus AV212CDM balance.

\section{RESULTS}

\subsection{Past information analysis from Maria Spring}

The analyzed period ranges from 1943 to 2016, with labels and literature data (Munteanu, Munteanu, 2011). Sometimes values are missing at some parameters, but there is enough data to evaluate the evolutions in good conditions. For a more specific expression, the mean concentration and standard deviation for the years studied were calculated. As a final result, this evolution was expressed as a percentage.

The highest concentration is for the bicarbonates and chlorides. Bicarbonates have the highest values at the beginning and end of the analyzed period. Between them, in 1983 and 1984, the values drop to $3500-2300 \mathrm{mg} / \mathrm{l}$. The first two determinations have maximum values: 1943 and 1951 nearly $7000 \mathrm{mg} / \mathrm{l}$. From the mean value $(4983 \mathrm{mg} / \mathrm{l})$ there is an error of $28 \%$.

The concentration of chlorides is much lower but still significant, namely at an average of $1145 \mathrm{mg} / \mathrm{l}$ the deviation is $17 \%$. Here the interval is shorter, only until 2008. The values are more uniform, the oscillations being practically between $1000-1500 \mathrm{mg} / \mathrm{l}$. And here the highest values are at the beginning of the interval, with the maximum in 1951: $1535 \mathrm{mg} / \mathrm{l}$. The minimum concentration was in 1978: $964 \mathrm{mg} / \mathrm{l}$. 

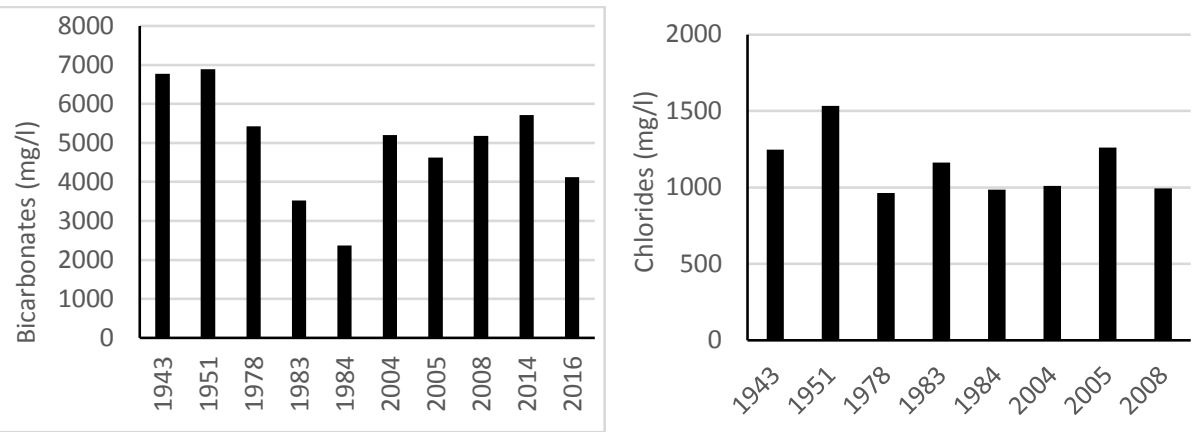

Fig. 2. Concentrations of bicarbonates and chlorates

Among other anions, sulphates have the higher concentration. Although four determinations are missing, it can be observed that the evolution was quite uniform. At an average concentration of $23 \mathrm{mg} / \mathrm{l}$, the error is $18 \%$. The variation amplitude is $9 \mathrm{mg} / \mathrm{l}$, with a maximum in $1978(28 \mathrm{mg} / \mathrm{l})$ and a minimum in $1983(19 \mathrm{mg} / \mathrm{l})$.

Nitrates were determined only in three years. Values range between $10 \mathrm{mg} / \mathrm{l}$ in 2004 and $6 \mathrm{mg} / \mathrm{l}$ in 1978. The error in these years is $24 \%$. About bromine are information from five years. Oscillations are high enough to be highlighted by the standard deviation of 2. The maximum was recorded in $1951(7.3 \mathrm{mg} / \mathrm{l})$ and the minimum in $2008(2.4 \mathrm{mg} / \mathrm{l})$. Iodine data is five years old. Here we see a progressive decrease in the values, from $2.6 \mathrm{mg} / \mathrm{l}$ in 1943 to $0.6 \mathrm{mg} / \mathrm{l}$ in 2008. They have the biggest error $(51 \%)$ of all the studied anions. Fluoride is present in very small quantities. No value exceeds $0.6 \mathrm{mg} / \mathrm{l}$, but the variation range is small. At an average subunit concentration and error is relatively low of $19 \%$.
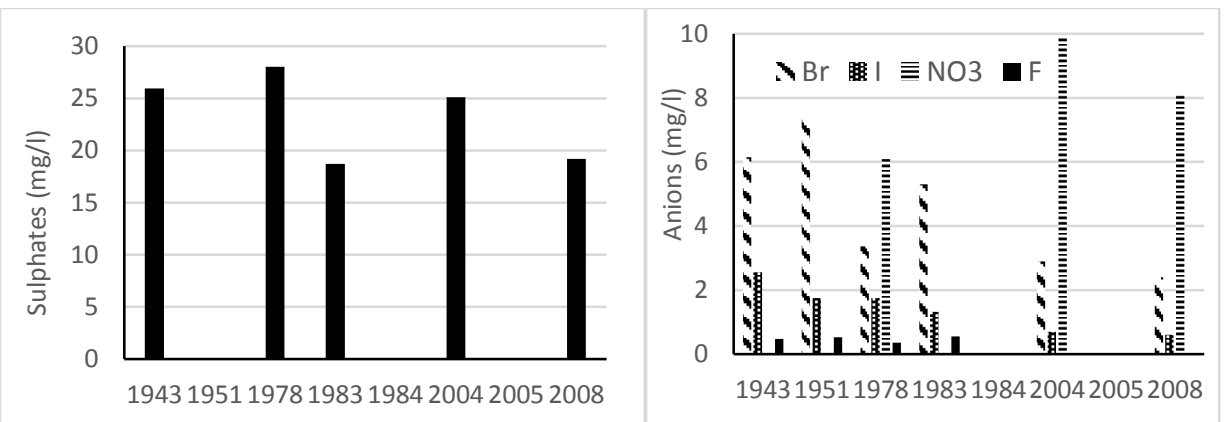

Fig. 3. Concentration of sulphates and other anions

The most important cations are sodium and calcium. Calcium has on average a high value of $200 \mathrm{mg} / \mathrm{l}$, but oscillations are significant with a $38 \%$ error. The maximum amplitude is recorded between $1983(324 \mathrm{mg} / \mathrm{l})$ and $2016(55 \mathrm{mg} / \mathrm{l})$. Of the other cations, the highest values are potassium. There is a very good constancy of values (between $67-84 \mathrm{mg} / \mathrm{l}$ ), although there are three years of measurement missing. Magnesium has a very high value in $1984(67 \mathrm{mg} / \mathrm{l})$. In the other years the values remain relatively constant, between $20-41 \mathrm{mg} / \mathrm{l}$. The mean concentration of 
$33.33 \mathrm{mg} / \mathrm{l}$ has a $41 \%$ error. Lithium was determined only in four years, and concentrations were very low, below $8 \mathrm{mg} / \mathrm{l}$, with deviation being among the smallest (17\%). Similarly, small values are for iron, which in all years do not exceed $10 \mathrm{mg} / \mathrm{l}$, but the deviation is maximum $70 \%$.
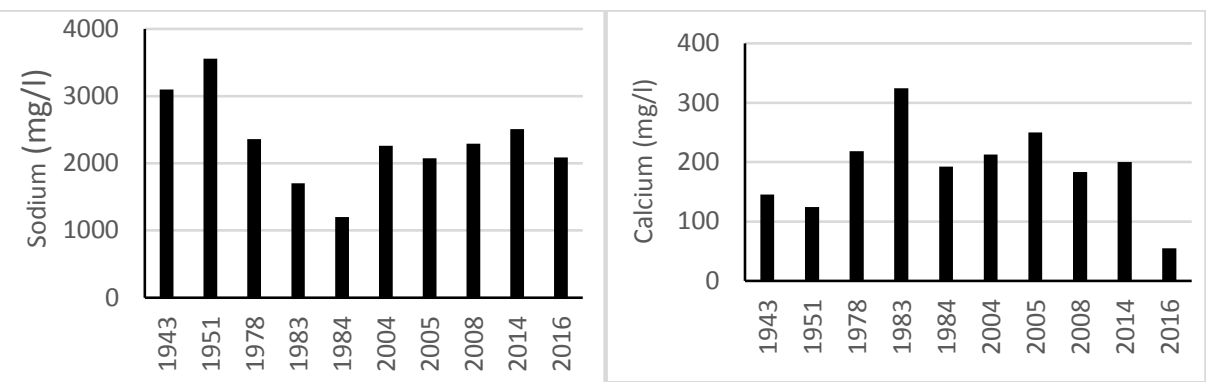

Fig. 4. Concentration of sodium and calcium

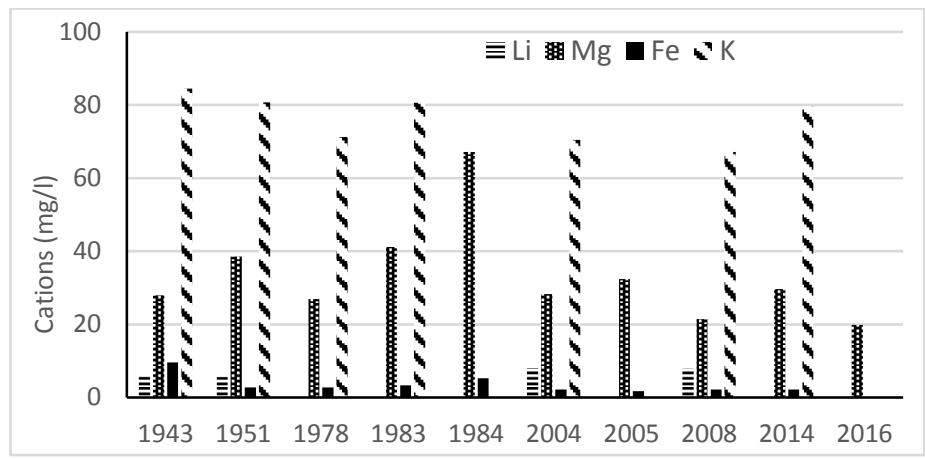

Fig. 5 Concentration of other cations

The other important parameters for the quality of mineral waters are carbon dioxide and mineralization. Both oscillations are not very high. Carbon dioxide is maintained between $1692-2440 \mathrm{mg} / \mathrm{l}$. Values of the mineralization degree have a high amplitude of $5914 \mathrm{mg} / \mathrm{l}$, which can be influenced by the number of anions and cations considered, as well as the weather conditions due to the alternation of rainy and dry years. At an average mineralization of $9872 \mathrm{mg} / \mathrm{l}$ corresponds a deviation of $21 \%$.

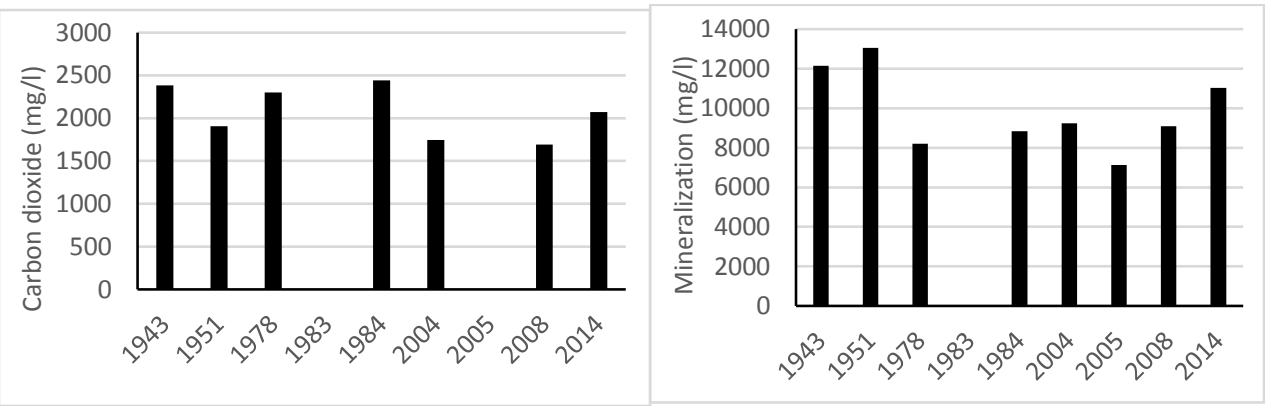




\section{Fig. 6. Concentration of carbon dioxide and mineralization}

\subsection{Analyzing new data from expedition measurements}

The measurements made at the resort show that the flows of the springs are very small. It is worth noting that from this evaluation is missing the Maria Spring, which is captured and cannot be measured in these conditions. Two springs have a slightly larger flow: Padi $63.4^{*} 10^{-3} \mathrm{l} / \mathrm{s}$ and Principal $62.5^{*} 10^{-3} \mathrm{l} / \mathrm{s}$. The lowest flow rate was measured at Victoria, only $3 * 10^{-3} 1 / \mathrm{s}$.

Water temperature is quite different, although the location of the springs is close. The cause may be the different depths from where water comes to the surface as well as the arrangement of springs. Ileana has the coldest water $\left(6^{\circ} \mathrm{C}\right)$, and Szemviz and Padi are the warmest $\left(10^{\circ} \mathrm{C}\right)$.

Table 1. Parameters determined on the field

\begin{tabular}{|c|c|c|c|c|c|c|}
\hline & Mioara & Ileana & Victoria & Principal & Szemviz & Padi \\
\hline Temp. $\left({ }^{\circ} \mathrm{C}\right)$ & 8 & 6 & 7 & 7 & 10 & 10 \\
\hline Flow $(1 / \mathrm{s})$ & $8.3^{*} 10^{-3}$ & $8.9^{*} 10^{-3}$ & $3 * 10^{-3}$ & $62.5^{*} 10^{-3}$ & $12.5^{*} 10^{-3}$ & $63.4^{*} 10^{-3}$ \\
\hline
\end{tabular}

Water samples were analyzed in the laboratory with the help of several devices. Six parameters were determined. Concentration of hydrogen ions varies between 7.26 at Mioara and 6.62 at Szemviz. The most alkaline are the sources Szemviz and Padi, with values of 6.62 and 6.64 , respectively.

The redox potential reflects the predominance of metal ions at negative values and oxides at positive values. The springs Mioara, Ileana, Victoria and Principal have negative values, with a very large variation (Mioara $-23.7 \mathrm{mV}$, Principal $-1.7 \mathrm{mV}$ ). Instead, at the Szemviz and Padi springs, the redox potential is positive. Here the values are almost identical $(9.6 \mathrm{mV}$ and $9.4 \mathrm{mV}$ respectively).

Concentration of ions exceeds $1000 \mathrm{mg} / \mathrm{l}$ at two sources: Szemviz $1430 \mathrm{mg} / \mathrm{l}$ and Padi $1460 \mathrm{mg} / \mathrm{l}$. Particularly small is the value at the Mioara Spring, only $419 \mathrm{mg} / \mathrm{l}$.

Salinity greatly reflects the momentary situation and weather conditions through low values that should generally be higher. Because these subunit percentages (max.0.4\%o) are consistent with the TDS are not considered as an error.

Table 2. Parameters determined with multiparameter

\begin{tabular}{|l|c|c|c|c|c|c|c|c|}
\hline \multicolumn{1}{|c|}{$\begin{array}{c}\text { Para- } \\
\text { meter }\end{array}$} & $\begin{array}{c}\text { Unit. } \\
\text { măs. }\end{array}$ & $\begin{array}{c}\text { Mas. } \\
\text { aparat. }\end{array}$ & Mioara & Ileana & Victoria & $\begin{array}{c}\text { Princi } \\
\text { pal }\end{array}$ & $\begin{array}{c}\text { Szem } \\
\text { viz }\end{array}$ & Padi \\
\hline $\mathrm{pH}$ & & WTW & 7.26 & 6.96 & 6.88 & 6.81 & 6.62 & 6.64 \\
\hline $\begin{array}{l}\text { Redox } \\
\text { poten. }\end{array}$ & $\mathrm{mV}$ & $\mathrm{WTW}$ & -23.7 & -9.1 & -3.5 & -1.7 & $+9,6$ & +9.4 \\
\hline $\begin{array}{l}\text { Ions } \\
\text { concentr. }\end{array}$ & $\mathrm{mg} / \mathrm{l}$ & $\mathrm{C} 933$ & 419 & 708 & 887 & 925 & 1430 & 1460 \\
\hline Salinity & $\% 0$ & $\mathrm{C} 933$ & 0.4 & 0.4 & 0.0 & 0.2 & 0.0 & 0.0 \\
\hline TDS & $\mathrm{mg} / \mathrm{l}$ & $\mathrm{C} 933$ & 1283 & 1162 & 452 & 883 & 419 & 227 \\
\hline $\begin{array}{l}\text { Fixed } \\
\text { residue }\end{array}$ & $\mathrm{mg} / \mathrm{l}$ & $\begin{array}{c}\text { Memm } \\
\text { ert }\end{array}$ & 2840 & 4400 & 1420 & 2880 & 1360 & 760 \\
\hline
\end{tabular}


Dissolved substances are present in large quantities, which reflects the quality of mineral water. Two springs have TDS above $1000 \mathrm{mg} / \mathrm{l}$ : Mioara $1283 \mathrm{mg} / \mathrm{l}$ and Ileana $1162 \mathrm{mg} / \mathrm{l}$. The poorest water in dissolved substances is the Padi Spring, $227 \mathrm{mg} / \mathrm{l}$.

Fixed residue quantities are also high. In addition to Mioara and Ileana (2840 $\mathrm{mg} / \mathrm{l}$ and $4400 \mathrm{mg} / \mathrm{l}$ respectively), there is a large amount of residue in the Principal Spring $(2880 \mathrm{mg} / \mathrm{l})$. As with the TDS, the lowest value was found at the Padi Spring (760 mg/l).

\section{CONCLUSIONS}

The springs from Malnaş Băi are an important hydromineral source, with multilateral uses. The most important source is Maria Spring, whose capacity was enlarged by the Siculia probe. For a short period, since 1916, the water of the Principal Spring has also been bottled. The other springs have small flows and, although grouped in a tight perimeter, have relatively physico-chemical parameters. Significant values of lithium and potassium are important because the basement is not rich with these elements, and the high concentration is rarer.

The standard deviation presents a wide range of variations between $8 \%$ and 70 $\%$, which puts into question the methodology for obtaining concentrations, especially the old ones that were made in Budapest and Miskolc, and the comparability of data due to the methods used.

The main parameter for determining the mineralization is the fixed residue. According to the Romanian legislation and the European Directives (Feru A., 2012) the values from the sources of the Malnaş Băi springs fall into the category of medium (Victoria, Szemviz, Padi) and rich mineralization (Mioara, Ileana, Principal).

\section{REFERENCES}

1. Feru A. (2012), Ghidul apelor minerale naturale, NOVIS, București

2. Harko J. (1972), Fluctuația debitului de apă în raport cu variația precipitațiilor la izvoarele de ape minerale de la stațiunile Malnaș-Băi și Bodoc din județul Covasna, Aluta

3. Jánosi Cs., at al. (2005), Székelyföldi fürdök, gyógyvizek, ARS TORIA, Budapest

4. Kisgyörgy Z. (2009), Kovászna megye, Pallas Ak., Csíkszereda

5. Munteanu C. (2009), Răspunsul glial la litiu şi apa minerală litiniferã Maria de la Malnaş-Bãi, Teza de doctorat (rezumat)

6. Munteanu C., Munteanu D. (2011), Ape minerale litinifere, Ed. Balneară, București

7. Szabó Á., Bogdan D., Kisgyörgy Z. (1978), Contribuțiii privind studiul radioactivității apelor minerale și a mofetelor de la Covasna, Băile Bálványos și Malnas Băi, jud. Covasna, Aluta 10-11, Sf. Gheorghe

8. Szekely Z. (1980), Studii și comentarii, Aluta X-XI, Muzeul Sf. Gheorghe

9. https://www.bailetusnad.ro/malnas-bai/ 